\title{
A critical analysis on the application of the legal principle of rule of law in the criminal justice system of Sri Lanka
}

\begin{abstract}
It is the responsibility of the State to protect its citizen from crimes and criminals. The main objective of criminal justice is to provide justice for the victim, offender and society at large. The criminal justice system aims to uphold the safety of the people and the crime free and peaceful society by extending its role to reduce the degree of crime commissions, to protect the rights of the parties in a criminal matter, to ensure the fair and speedy disposal of the criminal cases, to enhance the process of the rehabilitation of offenders, promote the treatment of victims and witnesses, improve people's feeling of safety and develop confidence in the criminal justice system. The main agencies of the criminal justice system have to play a vital role in this regard. However, there are some concerns as to whether Sri Lanka has an effective criminal justice system which could successfully achieve the above said objectives of criminal justice. There is also a question whether the main agencies of the criminal justice system of Sri Lanka would effectively function as to sustain the principles of legality, ensure the equality before the law and maintain law and order, in other words to uphold rule of law and governance in the country. Therefore, this paper intends to discuss the relationship between the rule of law and criminal justice system by evaluating/ examining the constitutional provisions, the substantive criminal law and procedural laws and laws relating to executive (law enforcement and correctional) and judicial functions. To complete the paper the study engages in library research rigorously and field research to a certain extent
\end{abstract}

Keywords: constitutional rights rule of law, police, the courts, prisons, law of criminal procedure
Volume 4 Issue 3 - 2017

\author{
Niriella MADSJS \\ Department of Public and International Law, University of \\ Colombo, Sri Lanka
}

\begin{abstract}
Correspondence: Muthukuda Arachchige Dona Shiroma Jeeva Shirajanie Niriella, Senior Attorney-at-Law; Commissioner for Oaths, Company Secretary, Notary Public, Senior Lecturer Department of Public and International Law, Faculty of Law, University of Colombo, Sri Lanka, Tel 94-I I-2585639; +94-03।2226839; +94-03 I-2223239; +94-07I-8043 I85, Fax 940 I I 250200I,Email jeevaniriella@gmail.com, jeeva@law.cmb.ac.lk, jecvaniriella@yahoo.com
\end{abstract}

Received: March 01, 2017| Published: March 23, 2017

\section{Introduction}

Ever since the beginning of human civilization, crime has been an unsolved problem. There is hardly a society which is not struggling with the problem of crime and no one can escape the subject of crime in day to day life. Sri Lanka is not an exemption to this phenomenon. The media reveal many stories and information about crimes daily and some of us might have encountered crimes more directly as victims. This may be one of the reasons that crime is one of the top concern subjects in Sri Lanka. Prevention of crimes, protection of the people from crimes and imposition of appropriate degree of punishment on the offenders are some of the major issues relating to the crime problem in Sri Lanka. The increase of crime rate including its brutality and rise of recidivism symbolize the dilemma faced by the main agencies (police, courts and correctional institutions) of the criminal justice system of the country today. These State institutions have the responsibility to apprehend, adjudicate, punish and correct the wrongdoers to achieve the safety of the people and the peaceful society. This could be possible by extending their functions to reduce the level of crime commissions, protect the rights of the parties in a criminal matter ensuring the fair and speedy disposal of the criminal cases, improve the process of the rehabilitation of both offender and victim and reintegrating them into the society appropriately. However, there is a concern whether the main agencies of the criminal justice system of Sri Lanka adhere to the principles of rule of law in carrying out their tasks to achieve the aforementioned goals. This paper intends to discuss the relationship between the rule of law and criminal justice system by evaluating the provisions of the Constitution and other relevant statutes relating to the functions of the said main agencies in Sri Lanka.

\section{The concept of rule of law}

At the outset it is pertinent to explore the definition (meaning) of the concept of rule of law, main principles of the concept and the modern loom/appearance of the concept as to provide a clear approach to the discussion. Laws are emanated from and enforced by the State. People living in an organized society have to follow these laws in order to live in peace and harmony and to maintain order in that particular society. It is the function of the State to enforce these laws on people. The responsibility of the State is to enforce such laws over all persons in the same manner. ${ }^{1}$ This philosophy gives birth to the concept of rule of law. Supremacy of the law and equality of all persons before the law, are the basis of the concept of rule of law. It means, law is the highest entity of ruling and all people should obey the law and it is applied to all without any discrimination. The concept of rule of law was familiar to ancient philosophers such as Aristotle. It was popularized by A.V. Dicey, ${ }^{2}$ a British Constitutional Scholar in the 19th century. The concept of rule of law implies that every citizen

${ }^{1}$ As stated in the abstract it is also the responsibility of the State to protect its citizen from crimes and criminals.

${ }^{2}$ Wormuth, Francis, 1949, The Origins of Modern Constitutionalism, Penguin p. 28; Bingham, Thomas, 2010, The Rule of Law, Penguin, p. 3. 
is subjected to the law and there is nothing above law. According to Dicey, (in his Introduction to the Study of Law of the Constitution) the concept of rule of law could be summarized in three rules/principles. They are:

a) No man should be punished or be made to suffer (body or property, movable and immovable), legally except for a breach of the law established in the law and judicial trial conducted against the person for that breach of law before a competent court of law in the land. In other words there must be supremacy of law, no one shall be punished except for definite breach of law, people must behave, act and perform according to the law of the land and the breach of law must be proved in a duly constituted court of law in order to punish the offender; ${ }^{3}$

b) No person is above law and every person (citizens of the country) irrespective to his position or condition, is subjected to the ordinary law of the State and agreeable to the jurisdiction of ordinary tribunals and courts that have the authority to implement the law emanated by the State. In other words all are equal before the law, every citizen is subjected to the ordinary law of the land and the citizen has to face trial in the same law court, irrespective of his status or position in the society; ${ }^{4}$

c) The rule of law is the result of statutes and judicial decisions determining the rights of individuals. ${ }^{5}$

Today, rule of law is considered as an integral part of justice. The United Nations Organization (UN), the foremost international institution established to protect rights of the people universally, also strongly respects this notion. For the UN, the rule of law refers to the principle of governance in which all persons, institutions and entities, public and private, including the State, are accountable to laws that are publicly promulgated, equally enforced and independently adjudicated and which are consistent with international human rights norms and standards. It requires ensuring adherence to the principles of supremacy of law, equality before the law, accountability to the law, fairness in the application of the law, separation of powers, participation in decision-making, legal certainty, avoidance of arbitrariness and procedural and legal transparency. ${ }^{6}$ According to $\mathrm{UN}$, the following four universal principles are upheld in the concept of rule of law. They are:

1) The State and its officials and representatives as well as private entities and individuals are accountable under the law;

2) The laws should be clear, just, stable and publicized and should be applied equally, and protect fundamental rights, including the security of persons and property;

3) The process by which the laws are enacted, administered and enforced should be accessible, fair and efficient and

4) Justice should be delivered timely by competent, ethical and independent body. ${ }^{7}$

${ }^{3}$ Further see www.publishyourarticles.net/eng/articles/define-law-and-discussthetheory-of-rule-of-lawhtml accessed on 30th January 2014

${ }^{4} I B I D$

${ }^{5}$ IBID

${ }^{6}$ Quoted from the Report of the Secretary-General on the Rule of Law and Transitional Justice in Conflict and Post-Conflict Societies www.un.org/en/ ruleoflaw Accessed on 30th January 2014.

${ }^{7} I B I D$
The above said principles are visible in the treaties, declaration and other instruments adopted by the UN time to time in order to establish the norms of the rule of law universally. Therefore, it is reasonable to state here, when a State becomes a member to a particular treaty by ratifying it, the State has the responsibility to implement all those norms through their domestic laws. The next paragraph will briefly express Sri Lanka's position with regard to being a member to the international treaty law. In 1955, Sri Lanka gained admission to the UN. Sri Lanka is a member State to the many of the International Conventions established by the UN namely; International Covenant on Civil and Political Rights, International Covenant on Economic, Social and Cultural Rights, Convention on the Elimination of all forms of Discrimination Against Women, International Convention on the Elimination of All Forms of Racial Discrimination, Convention on the Rights of the Child, ILO Convention on the Worst Forms of Child Labour, Convention Against Torture, and Other Cruel, Inhuman or Degrading Treatment or Punishment, Optional Protocol to the International Covenant on Civil and Political Rights, Optional protocol to the Convention on the Rights of the Child on the involvement of children in armed conflict, Optional Protocol to the Convention on the Elimination of Discrimination against Women, Optional protocol to the Convention on the Rights of the Child on the Sale of Children, Child Prostitution and Child Pornography, International Convention on the Protection of the Rights of All Migrant Workers and Members of Their Families, Convention on the Rights of Persons with disabilities; Although, Sri Lanka has signed the flowing treaties not yet ratified them. They are Conventions against Transnational organized Crime, Protocol to Prevent, Suppress and Punish Trafficking in Persons, Especially Women and Children, and the ILO Minimum Age Convention. Therefore, one may argue that the State of Sri Lanka must adhere to the aforementioned principles (or in other words the principles of rule of law) in enacting and enforcing laws over the citizens of the country.

\section{Criminal justice system in Sri Lanka and rule of law}

Criminal Justice system is an instrument of social control. It refers to the State agencies/organs that discharge their functions in relation to enforce law (police), adjudicate crimes (the courts) and correct the criminal behavior of the offender (correctional institutions) in order to achieve its main objectives, namely detecting the offenders and bringing them before the law, conducting a fair trial to find the real offender, convicting the offender and imposing an appropriate degree of punishment on the offender, rehabilitating and reintegrating the offender into the society, controlling and prevent further crimes, provide the justice to all the parties who were involved in a criminal matter and ensuring the protection of the people in society from crimes and criminals/wrongdoers. The applicability of the notion of the rule of law in criminal law (or in other words the relationship between rule of law and criminal law) was discussed by Sir Ivor Jennings in his book titled "The law and the Constitution. He says that 'In the criminal law, indeed the rule of law implies a combination of the notion of equality before the law with the notion that the limits of police powers should be rigidly defined. The rule of law in this sense is expressed in the maxim, derived from 19th century liberalism, nulla poena sine lege..."8 Further, he stated that Jerome Hall has pointed out the applicability of rule of law in criminal law under four

${ }^{8}$ Sir Ivor Jennings, 1975, The Law and the Constitution, University of London Pres, p. 51. 
notions where the relationship between criminal law and rule of law is revealed. According to Jerome Hall, the four norms are as follows: ${ }^{9}$

a) The category of crimes should be determined by general rules of a more or less fixed character;

b) Person should not be punished except for a crime which falls within these general rules;

c) Penal statutes should be strictly construed, so that no act may be made criminal which is not clearly covered by the statutes and

d) Penal laws should never have retrospective effect.

Since criminal law is part of the criminal justice, one may correctly claim that there is a strong relationship between an effective crimina justice system and the concept of rule of law. Therefore, the criminal justice system should constitute the unbiased mechanism to redress the grievances and bring action against perpetrators who committed crimes (or in other words who committed offences against the society) in order to uphold the notion of rule of law. Therefore, an effective criminal justice system is capable of investigating and adjudicating criminal offences efficiently, impartially, and without improper interventions while ensuring the rights of the suspects and victims are being protected and also capable in reducing the crime rate especially the recidivism rate. In this context the following discussion focuses on the rights guaranteed by the Constitution of Sri Lanka (the Supreme Law of the country) and procedural laws relating to control the actions of the law enforcement agencies, the police, in order to protect the rights of the parties involve in a criminal matter especially the suspect/ accused.

\section{Police and law enforcement}

In the event of a crime, the police are the agency that primarily plays the role in the criminal justice process whose function is first to arrest and detain the suspect, interrogate the relevant people during investigative process, search the premises and then form the charges and finally lead the evidence in the trial. In this process, on one hand the police need freedom to enforce the law as they see fit and on the other hand the rights of the citizens recognized by the constitution should not be violated when they use their power. Many critical issues have emerged in this regard.

\section{Custodial interrogation}

The Article 13 of the Constitution ${ }^{10}$ guarantees certain important fundamental rights for the accused; freedom from arbitrary arrest, ${ }^{11}$ detention, ${ }^{12}$ punishment and prohibition of retroactive penal legislation. The Article 13 (5) stipulates that every person shall be presumed innocent until he is proven guilty and further, it provides

${ }^{9}$ Jerome Hall, Nulla Poena Sing Lege, Yale Law Journal, Vol. XLVII p165, in Sir Ivor Jennings, The Law and the Constitution, p. 51.

${ }^{10}$ The Constitution of the Democratic Socialist Republic of Sri Lanka enacted in 1979 .

${ }^{11}$ Article 13 (1) says, that No person shall be arrested except according to procedure established by law. Any person arrested shall be informed of the reason for his arrest.

${ }^{12}$ Article 13 says that Every person held in custody, detained or otherwise deprived of personal liberty shall be brought before the judge of the nearest of personal liberty shall be brought before the judge of the nearest competent

court according to procedure established by law and shall not be further held in custody, detained or deprived of personal liberty except upon and in terms of the order of such judge made in accordance with procedure established by law that the burden of proving of the particular facts may, by law, be placed on an accused person. The Article 11 states that no person shall be subjected to torture or to cruel, inhumane or degrading treatment or punishment. These Articles could be interpreted as meaning that the law enforcement authorities cannot use any force including physical or psychological against the suspect/accused to get them to confess or give information relating to the particular crime. The rights intended to preserve by the above said articles are directly related to police functions of obtaining statements (interrogation) from the suspect/ accused in a criminal matter. The Evidence Ordinance No. 14 of 1883 includes provisions relating to the admissibility of the statements made by the suspect or accused. It states that the confession ${ }^{13}$ must be made voluntarily by the suspect if it is to be admissible as evidence in a criminal trial. In Cooray (1926) 28 NLR (New Law Reports) 74; Kalubanda (1912) 15 NLR 422; Ukkubanda (1923) 24 NLR 372; Weerakkone v Ranhamy (1926) 27 NLR 267; Nambiar v Fernando (1925) 27 NLR 404;Anandagoda (1960) 62 NLR 24, the court emphasized that confessions means an admission made by the suspect or accused suggesting the inference of commission of the offence by him. Confession extracts from the suspect through coercion, trickery or promise ${ }^{14}$ of leniency are inadmissible due to lack of the trustworthiness of such statements. In Weerasamy ( 1941) 43 NLR 152, the court held that the Crown should establish the relevancy of confession by leading evidence to show that it was made voluntarily. In Amaris Appoo 1 NLR 209; Martin Singho (1964) 66 NLR 391; Kalimuttu (1966) 69 NLR 349; Gunaseela Theoro (1968) 73 NLR 154 court emphasized that the confession extracts from the suspect under any influence or promise or making any threat is inadmissible at the criminal trial. The rule of voluntariness (the exclusionary rule) applies to confession obtained at any time whether the suspect is in police custody ${ }^{15}$ or not. ${ }^{16}$ However, a confession is admissible evidence against the accused if it comes under the sphere of the Section $27^{17}$ of the Evidence Ordinance or if the statement is made before a judicial

${ }^{13}$ Section 17(2) of the Evidence Ordinance says that 'A confession is an admission made at any time by a person accused of an offence stating or suggesting the inference that he committed that offence.'

${ }^{14}$ Section 24 of the Evidence Ordinance says that 'A confession made by an accused person is irrelevant in a criminal proceeding1 if the making of the confession appears to the court to have been caused by any inducement, threat, or promise having reference to the charge against the accused person, proceeding from a person in authority, or proceeding from another person in the presence of a person in authority and with his sanction, and which inducement threat, or promise is sufficient in the opinion of the court to give the accused person grounds, which would appear to him reasonable, for supposing that by making it he would gain any advantage or avoid any evil of a temporal nature in reference to the proceedings against him'.

${ }^{15}$ Section 26(1) of the Evidence Ordinance says that 'No confession made by any person whilst he is in the custody of a police officer, unless it be made in the immediate presence of a Magistrate should be proved as against such person.' In the following case law it was emphasized that any confession is made by the suspect is not admissible evidence against him unless it is made in the presence of the Magistrate. E.g. Tennakoon Mudiyanselage Appuhamy (1958) 60 NLR 313.

${ }^{16}$ Section $25(1)$ of the Evidence Ordinance says that 'No confession made to a police officer should be proved as against a person accused of any offence.' In following cases the court decided that a confession made to a police officer is not admissible evidence against the accused - Gnanaseeha Thero (1968) 73 NLR 154; Murugan Ramasamy (1964) 66 NLR 265.

${ }^{17}$ Section 27(1) of the Evidence Ordinance Provided that, when any fact is deposed to as discovered in consequence of information received from a person accused of any offence, in the custody of a police officer, so much of such information, whether it amounts to a confession or not, as relates distinctly to the fact thereby discovered may be proved. 
officer even if the suspect is in police custody. ${ }^{18}$ Piyadasa (1967) 72 NLR 434; Sugathapala (1967) 69 NLR 457 are classic examples.

The procedural law relating to obtaining the statements from the suspect is governed by the sections 110 and 111 of the Code of Criminal Procedure Act No.15 of 1979. According to section 111, a police officer should not offer or make any inducement, threat or promise to any person charged with an offence to induce such a person to make any statement with reference to the charge against the person. However, this provision does not prevent the suspect from making any statement on his/her own free will. ${ }^{19}$ According to section 110 (1) and (2) of the Code of Criminal Procedure Act No 15 of 1979 , the police officer who is making an investigation may ask questions regarding the crime from any person. According to section 110 (2) of the Code Criminal Procedure Act, any person supposed to be acquainted with the facts and circumstances of the case should answer the question other than the questions which would have a tendency to expose him to criminal charges or to a penalty of forfeit. Therefore, the suspect is also bound to answer the question without remaining silent. ${ }^{20}$ The suspects are being ill treated/tortured by the police officers during the police investigation in order to obtain confessions or information relating to the alleged offence. There are several instances where the suspects are being tortured in custodial interrogation. Some of them are as follows: Angulana Dual Murder Case which is an unreported case where the two suspects were badly assaulted by the police officers to make them confess. Samarasinghe Sudath Pushpakumara is another case ${ }^{21}$ where the suspect was arrested for the offence of robbery and forced him to make a confession by admitting the commission of the offence of robbery with the notorious thief. In Mulankandage Lasantha Jagath Kumara ${ }^{22}$ the suspect was tortured while he was in the police custody and forced him to make a confession. In Ranjith Sumangala ${ }^{23}$ case the suspect was arrested and detained for several days and obtained a confession forcefully. The aforementioned cases are a few illustrations to prove that there is a doubt in the applicability of the principles of rule of law in relation to the custodial interrogation.

\section{Arrest and detention}

Police officers are the gatekeepers of the criminal justice process. They use their power of arrest to initiate the justice process. Generally speaking, a person will be said to be detained when a State official restrains the person's liberty including cases where the person reasonably perceives that he is not free to come and go as they please. Being free from arbitrary arrest is one of the fundamental rights

\footnotetext{
${ }^{18}$ Section $26(1)$ of the Evidence Ordinance.

${ }^{19}$ Section 126 of the Code of criminal procedure Act says that 'any peace officer or person in authority should not make any inducement, threat or promise any person charge of with any offence to induce such person to make any statement having reference to the charge against such person but any peace officer or other person shall not prevent or discourage by any caution or otherwise any person for making any statement which he may be disposed to make of his own free will'. Section 127 of the Code of Criminal Procedure says that A Magistrate should not record any confession statement unless upon questioning the person making it he has reason to believe that it was made voluntarily, and when he recodes any such statement he should make a memorandum at the foot of such record.

${ }^{20}$ Section 100 (2) of the Code of Criminal Procedure Act No 15 of 1979

${ }^{21}$ Asian Legal Resource Centre (AHRC) -UAC -012-2011.

${ }^{22}$ Supreme Court Fundamental Right Appeal Case. No 471/2000.

${ }^{23}$ AHRC Police Cases 1988-2011.
}

guaranteed by the Constitution of Sri Lanka. ${ }^{24}$ Chapter IV of the Code of Criminal Procedure Act No. 15 of 1979, governs the law relating to arrest and detain of the suspect and search the premises. According to the section 23 (1) of the Code of Criminal Procedure Act, making an arrest means that the police officer should actually touch or confine the body of the suspect unless there is a submission to the custody by word or action by the police officer and detain means keeping the person in police custody. However, today, arrest and detention do not necessarily mean confinement in a police station but stopping a person in any place and interrogating him without any reasonable reasons or ground also may amount to an arrest and detain which is arbitrary and it leads to violation of the fundamental right guaranteed by the Article 13 (1) of the Constitution. ${ }^{25}$ For instance, Sirisena vs. Perera (1991) Sri Lanka Law Report (SLR) 97; Wickramabandu v Herath (1980) 2 SLR 348; Piyasiri v Fernando (1981) 1 SLR 173; Namasivayagam V Gunawardae (1989) 1 SLR 396; Rajapakse v Kudahetti (1992) 2 SLR 223 and more importantly Somawathie v Weerasinghe and Lundstron v Herath. In these cases it was further emphasized by the court that the protection of the Article 13 (1) of the Constitution is not confined only to a person who is arrested on suspicion of having committed or being concerned with an offence. It is important to note here that the provisions of the Code of Criminal Procedure Act are not applicable in case of preventive detention. Preventive detention is where detaining a person is considered as a threat to the State. When a State has declared any emergency situation under section 2 of the Public Security Ordinance No 25 of the 1947, the section 5 of the same Ordinance empowers the President to make regulations that are essential to ensure the public security. Section 5 (2) (a) provides that the regulations made under section 5 (2) may authorize the preventive detention of persons. Therefore, in such situations any person can be detained for preventive purpose. Emergency Regulation No. 17 under Public Security Ordinance stipulates the legal permission for (preventive) detention of a person on the order of the Secretary of Defence with a view of preventing him from acting in any manner prejudicial to national security or to the maintenance of public order. Emergency Regulations No. 18 and 19 refer to the arrest of a person relating to offences prescribed in the Emergency Regulations. According to the Emergency Regulations $2005^{26}$ preventive detention without trial on security grounds for up to one year is authorized. The regulation excludes judicial review ${ }^{27}$ and declares all such detentions

${ }^{24}$ The article 13 (1) of the Constitution stipulates that no one should be arrested except according to the procedure established by law and the arrested person must be informed of the reasons for his arrest and the article 13 (2) of the Constitution states that every person held in custody, detained or otherwise deprived of personal liberty shall be brought before the judge of the nearest competent court according to procedure established by law, and shall not be further held in custody, detained or deprived of personal liberty except upon and in terms of the order of such judge made in accordance with procedure established by law. Article 13 (4) says that no person shall be punished

with death or imprisonment except by order of a competent court, made in accordance with procedure established by law. The arrest, holding in custody, detention or other deprivation of personal liberty of a person, pending investigation or trial, shall not constitute punishment.

${ }^{25}$ Further see the Article13 (1) which states that "No person shall be arrested except according to procedure established by law. Any person arrested shall be informed of the resons for his arrest. "

${ }^{26}$ Emergency Regulation 19. See further, Regulation 1.

${ }^{27}$ Emergency Regulation 19 (10). See further, section 8 of Public security Ordinance- No emergency regulation and no order, rule or direction made or given thereunder shall be called in question in any court. Visualingam v Liyange (1984) 2SLR 123; Adirisuriya v Navaratnam (1985) 1 SLR 100 
are lawful. ${ }^{28}$ In addition to the Emergency Regulations, the Prevention of Terrorism Act No. 48 of 1979 also recognizes validity of the preventive detention of a person. According to the Act, if a person who commits any of the offence mentioned in section 2 of the Act or if the Minister of Defence in the country has reasons to believe or suspect that any person is connected with or concerned in any unlawful activity under this Act, the minister may order such person to be detained. ${ }^{29}$ However, a reasonable question arises as to whether this type of unlimited or unconstrained law can be enacted by the legislature and this type of laws themselves cause to violate the rights of the people which are recognized under rule of law. ${ }^{30}$

Right to be promptly informed of the reasons for arrest ${ }^{31}$ is one of the rights guaranteed by the Constitution. It protects the individual privacy against certain types of arbitrary inferences of the law enforcement agencies. Nevertheless, it does not provide a general unlimited constitutional right to privacy for people which caused to obstruct the main objectives of the criminal justice. The Code of Criminal Procedure Act sets out its provision as to protect the above said right. The section 23 (1) stipulates that the person who is subjected to arrest should be informed of the reasons for such arresting. However, the permission given to the law enforcement officers by section 23 (2) of the Code to use their force reasonably and appropriately when the accused/suspect forcibly resists the endeavor to arrest him or attempt to evade the arrest, leads to violate the guaranteed right. The phrase '...... reasonably and necessary to affect the arrest.....' in the section is very much subjective to the circumstances. It provides a protection to abuse and exceed the given power in a legitimate manner. The right to be brought promptly before a judge is another right guaranteed by the Constitution of Sri Lanka. ${ }^{32}$ The Criminal Procedure Code sets out some provisions with regard to produce the suspect without any delay. According to section 37 of the Criminal Procedure Code, a person who is arrested under suspicion for any offence should not be detained for more than 24 hours. However, according to section 115 in the Code, Magistrate may extend the detention period for fifteen days, considering the request made by the police offices, if there is a necessity of further investigation. This detention period was extended up to 48 hours in the case of cognizable offences with the amendment No 2 to the Code in $2013 .{ }^{33}$ The new provision has made a clear distinction between some cognizable offences and non-cognizable offences with regard to produce the suspect before the court. Since the new amendment is only applicable to the offences listed in the amendment it also leads to create a difference between the cognizable offences listed in the new amendment and the offences which are not listed in the amendment.

\footnotetext{
${ }^{28}$ Emergency Regulation No 19 (3).

${ }^{29}$ Section 9 (1).

${ }^{30}$ See Hidramani v Ratnawale 75 NLR 67 ; Gunasekera v Ratnavale 76 MLR 316.

${ }^{31}$ The article 13 (1) of the Constitution stipulates that no one should be arrested except according to the procedure established by law and the arrested person must be informed of the reasons for his arrest.

${ }^{32}$ Article 13 (2) of the Constitution says that,every person held in custody, detained or otherwise deprived of personal liberty shall be brought before the judge of the nearest competent court according to procedure established by law, and shall not be further held in custody, detained or deprived of personal liberty except upon and in terms of the order of such judge made in accordance with procedure established by law.

${ }^{33}$ Section 2 of the Code of Criminal Procedure (Special Provisions) Act, No. 2 of 2013 .
}

\section{The Judicial process}

When the proceedings are instituted or in other words charges are made against the accused person after completing the police investigation, the court which is the next agency of the criminal justice system comes into play its role; conduct the trial to determine the culpability of the accused. In Sri Lanka, criminal offences are basically heard either summarily (by serving a charge sheet made by the police) in the Magistrate Court or by serving an indictment given by the Attorney-General which is heard in the High Court. High Court trials can be carried out with Jury or with trial at bar where three High Court Judges are appointed by the Chief Justice to conduct the trial. In addition to these trials, there is a special circumstance where the Magistrate is allowed to conduct the preliminary inquiry with regard to the non-summary offences. This particular part of the discussion mainly focuses on the rights guaranteed by the Constitution to the accused during the period of the trial and how the Code of Criminal Procedure Act sets out legal provisions to protect the rights ensured by the Constitution. Most of the procedural rights provided to accused in the trial process are found in the Articles 11, 12 and 13 (3) (4) and (5) of the Constitution. Article 12 guaranteed the equal protection before the law without any discrimination based on race, religion, language, cast, sex, political opinion and place of birth etc.. Therefore, any person who has violated the criminal law in the country should be tried according to the law of criminal procedure without any discrimination. In all criminal prosecutions, the accused shall enjoy the right to a fair trial by a competent court. ${ }^{34}$ The Article 13 (3) covers a wide range of rights that the accused can enjoy in the criminal justice process, especially during the trial process. It ensures several rights such as right to be tried within a reasonable time without any undue delay, right to public trial, right against self incrimination and right to be silent, right to understand the proceedings/right to information, right to participate in the trial and to represent an Attorney-at-Law on behalf of the accused/right to counsel, right to confront opposing witnesses, right to defend, right not to be convicted without a guilty mind, right to appeal, right not to be punished more than once for the same offence (right against double jeopardy) and right to be presumed innocent etc.

As far as the right to be tried within a reasonable time is concerned, in Sri Lanka, though there is no explicit Constitutional provision which guarantees this right, section 163 of the Code of Criminal Procedure Act says: A preliminary inquiry should be concluded within a month. However, if there are any reasonable reasons, the Magistrate has the power to record and prolong the inquiry beyond the period of one month. One may state here that the purpose of this section is to minimise:

a. The time period the accused spends in pre-trial custody under restrictive bail conditions,

b. Mental stress,

c. Pre-trial anxiety of the accused,

d. Possible deterioration of evidence during the pre-trial period.

However, there is no other provision to guarantee the above said right other than section 163 . Therefore, this is criticised by many

${ }^{34}$ Article 13 (3) of the Constitution states that 'Any person charged with an offence shall be entitled to be heard, in person or by an attorney-at-law, at a fair trial by a competent court' 
accused and their counsels according to the axiom, long delay and "never tried" which is very relevant to the criminal trials of Sri Lanka today. With regard to the right to public trial, section 136 states that the proceedings in the Magistrate's Court maybe constituted of a public servant (police officer or any other public officer) or the victim of criminal offence and in the High Court, the Attorney-General or State Counsel may institute the proceedings (section 191 (i) of the Code of Criminal Procedure Act). These sections reveal that the criminal trials should be held in the courts publicly. Right to silence is also accepted by the provisions set out in the Criminal Procedure Act. According to 146 of this Code, the accused can remain silent without answering to the Magistrate..$^{35}$ However, it is important to note here that if the accused keeps remaining silent at the trial, it is unfavourable to him as he appears guilty. Participation at the trail by him or with Attorney is respected in both summary and non-summary trials. ${ }^{36}$

Right to confront the witnesses is also recognized in the preliminary inquiry and in other trials. Section 148 (2) states that the accused may pose questions to each witness produced against him. According to section 148 (3), this right is guaranteed in the circumstance where the accused is not represented by an Attorney-at-Law. Section 199 (5) says the accused is permitted to cross-examine all witnesses called for prosecution. This right is a necessary component of a fair trial. Right to defence is another important legal right preserved by the Constitution through the procedural laws in the country. According to sections 150 and 151 of the Code of Criminal Procedure Act, the accused is given the opportunity to defend him/herself at the preliminary inquiry. The same right is well established in the High Court as a result of section 201 (1) of this Code. Section 260 also declares that every person accused before any criminal court may by right be defended by an attorney-at-law. ${ }^{37}$

The Code of Criminal Procedure Act sets out some provisions to protect the right to understanding the proceedings or right to information about the charges, evidence, statements made against the accused. According to section 146, a Magistrate conducting a preliminary inquiry should read over to the accused about the charge or charges in respect of which the inquiry is being held ${ }^{38}$ and he is entitled to obtain a (certified) copy of the evidence and statements given by the others to the police. ${ }^{39}$ With regard to summary offences, section 182 (1) states that when the accused is brought or appears before the court the Magistrate should inform the charges made against the accused and section 182 (2) stipulates that the Magistrate should ask the accused to present reasons as to why he should not be convicted. According to section 195 (b) \& (c) the High Court Judge should serve a copy of the indictment and its annexes and inform the accused of the date of trial and also should inform to select a jury if necessary at the beginning of the High Court trials. ${ }^{40}$ However, the (undue) delay of trial in many cases made a serious doubt of the protection of the fair trial in Sri Lanka which leads to less faith in the justice process in the country. The right not to be tried twice for the same criminal offence is also appreciated by the provisions in the

\footnotetext{
${ }^{35}$ Further see section $151(1)(2)(3)$.

${ }^{36}$ Section 191 of the Code of Criminal Procedure Act, No.15 of 1979.

${ }^{37}$ It is interesting state here, the right to defend was recognized under Administration of Justice Law No. 44 of 1973 which governed the criminal procedure prior to the current Criminal Procedure Code No 15 of 1979 Jayasinghe v Munasinghe (1959) 92 NLR 527; Premaratne v Gunaratne (1964) 71 NLR 113; Subramaniam vs I.P. Kankesanturai (1968) 71 NLR 204.

${ }^{38}$ Further see section 150 of the Code of Criminal Procedure Act

${ }^{39}$ Section 158 of the Code of Criminal Procedure Act.

${ }^{40}$ Further see section 204 of the Code of Criminal Procedure Act.
}

Code of Criminal Procedure Act ${ }^{41}$ and the Judicature Act (under the theory of double jeopardy). The objective of this particular provision is that if any person has been once tried by a competent court for a criminal offence and has been convicted/acquitted of such an offense, they should not be liable to be tried for the same criminal offence again.

At the post-trial stage of the criminal proceedings, perhaps the most important right for someone who has been found guilty of offense is the right to appeal against conviction. In Sri Lanka, a person convicted for a criminal offence can appeal against the conviction, the punishment imposed upon conviction or both. ${ }^{42}$ An appeal is not a rehearing of the trial and only certain aspects of the trial decision may be appealed. Generally, this is limited to situations where the trail judge has made an error in application of the law but findings of fact maybe addressed on appeal, though not for the purpose of re-trying the case. In particular, an accused has a right to appeal on the basis that the finding of guilt was unreasonable in the circumstances or cannot be supported by the evidence. The principles of fundamental justice and the right not to be deprived of liberty except in accordance with the law which proves one's guiltiness. The established basic principle of the criminal law is that no person can be found guilty without proving actus reus and mens rea, which especially means that no person can be punished without proving the guilty mind of that person. The Penal Code and the special statutes which prescribe the criminal offences deal with the substantive law relating to this principle. The procedural laws relating to this particular principle could be found in the Evidence Ordinance and the Code of Criminal Procedure Act too. The presumption of innocence lies at the heart of the criminal law and protects the fundamental liberty and human dignity of any person accused of a criminal offence. The fact that the state must prove the guilt of an accused beyond a reasonable doubt flows from the presumption of innocence in Article 13(5) of the Constitution of Sri Lanka. ${ }^{43}$

Protection against cruel, inhumane or degrading treatment or punishment is well guaranteed in the Constitution of Sri Lanka. ${ }^{44}$ In Sri Lanka, death penalty is a legally permissible mode of punishment. ${ }^{45}$ According to the nature of the execution one may say that death penalty is a cruel and inhuman punishment. Then a question arises whether the imposition of the capital punishment violates the provision of the Constitution. In accordance with Article 16 (1) of the Constitution, all existing written laws and unwritten laws should be valid and operative notwithstanding any inconsistency with the presiding provisions of the Chapter III (Fundamental rights chapter) of the Constitution and the imposing any form of punishment recognized by prevailing written law does not make any contravention of the provisions of the Chapter III. ${ }^{46}$ Therefore, imposing death penalty is not unconstitutional or violation of the Article 11 of the Constitution. According to Article 13(6), no person should be held guilty of an offense on account of any act or illegal omission which did not, at the time of act or omission, constitute such an offense, an no penalty shall be imposed for any offense more severe than the penalty in force at the time such offense was committed. It further

\footnotetext{
Judicature Act. Judicature Act.

${ }^{43}$ Further see sections $101-105$ of the Evidence Ordinance.

${ }^{44}$ Article 11 of the Constitution.

${ }^{45}$ Section 52 of the Penal Code.

${ }^{46}$ Further see Article 16 (2).
}

${ }^{41}$ Section 314 of the Code of Criminal Procedure Act; section 12 of the

${ }^{42}$ Section 320 (1) of the Code of Criminal Procedure Act; section 31 of the 
states nothing in this Article has prejudiced the trial and punishment of any person for any act or illegal omission which at the time when it was committed, was criminal according to the general principles of law recognized by the community of nations. Therefore, upon finding an accused guilty or plead guilty by the accused person, the court may impose a punishment on him/her. In Sri Lanka, the criminal law generally specifies the maximum sentences for the offences and a very few minimum sentences as mandatory, leaving a great deal of discretion in the hands of the trial judge in relation to the imposition of the sentence. Therefore, in Sri Lanka, the sentencing disparity is a frequent problem which is found in the criminal cases where the proportionality between the punishment imposed and the offense committed cannot be found. Therefore, one may argue that sentencing disparities in similar cases may be considered as cruel punishment for some offenders.

\section{Institutional corrections - prisons}

Prison $^{47}$ is one of the important correctional institutions which is involved in the criminal justice process. The offenders who are sentenced by imprisonment are sent to this particular institution for rehabilitation. The most important task or the main objective of the prison institution is to rehabilitate the prisoner thereby helping him/ her to understand what was wrong with his/her behavior and helping $\mathrm{him} /$ her to become a productive citizen in the future after release from prison. The prison system was established in Sri Lanka under the Prison Ordinance in $1877 .{ }^{48}$ Every year, the direct admission of unconvicted prisoners is more than the number of convicted prisoners. In the year 2013, the percentage of the un-convicted prisoners was $77.4 \%$ and the convicted prisoners' percentage $22.6 \%{ }^{49}$ Ratio of convicted to un-convicted prisoners in the year 2013 was 1:3. According to the information issued from the Department of Prison, direct admissions of both convicted and remands prisoners have considerably increased during the last decade. Although the number of admissions of prisoners has increased, the capacity of the prison system has not extended in shape at the same rate. The prisons are overcrowded and lead to violation of certain rights of the inmates. Although prisoners do not have full Constitutional rights like other free people, they are also protected by the Constitution's prohibition of cruel and unusual punishment. This protection requires that prisoners be afforded a minimum standard of living. Prisoners also retain some other Constitutional rights such as equal protection before the law who should be protected against unequal treatment on the basis of race, sex and religion etc.

The following prison regulations respect the Article 11 of the Constitution:

1. Regulation 248 which says before the execution of the punishment, the medical report of the offender should be taken into consideration.

${ }^{47}$ Prison is the only correctional institution which is discussed for the purpose of this study.

${ }^{48}$ Prison Ordinance No 16 of 1877

${ }^{49}$ See Table 3.13 on page 24, Prison Statistics of Sri Lanka Published by the Statistics Division, Prison Headquarters Sri Lanka in 2008.
2. Regulation 249 and 252 (e) which say iron shackles and iron equipment cannot be used to punish any prisoner in the prison.

Article 4 (d) of the Constitution says that the fundamental rights which the Constitution declared and recognized shall be respected and secured by all the organs of the government and should not be abridged, restricted or denied. Prison regulation 132, while respecting the above said Article, states the main responsibility of the prison officers is to treat the prisoners humanely and kindly without any exception. Under the directive principles of State policy and fundamental duties, the Parliament, the President and the Cabinet of Ministers should enact the laws in order to establish a just and free society. Therefore, all the Public Officers should take the necessary steps to provide an adequate standard of living for all the people in the country. ${ }^{50}$ The prison regulations 13 says that the Superintendent of the prison should ensure the daily needs of the inmates are provided adequately. Regulation 15 says the Superintendant should visit the prison hospital frequently and according to regulation 22 , he is responsible to provide medicine and other required needs to the sick prisoners according to the recommendations given by the prison doctor. The regulation 222 says all prisoners are entitled to nutritious meals and according to the regulation 50 they are entitled to clean drinking water and an adequate quantity of water for their daily basic needs. Segregation based on sex is one of the rights of the inmates in Sri Lanka. According to section 77 of the Prison Ordinance, male inmates should be kept separate from female inmates. Although Sri Lanka has the above said Constitutional provisions and prison rules and regulations to protect the rights of the prisoners, there are many incidents that have taken place in the prisons where the above said rights were violated. ${ }^{51}$

\section{Conclusion}

The above said discussion reveals the relationship between the concept of rule of law and the criminal justice system. It also discloses how Sri Lankan law, including the Constitution and the other penal laws, especially laws of criminal procedure, provide the provisions to adopt the principles of the rule of law in the criminal justice system. However, the violations of the rights of the suspects in the investigation process, rights of the accused in the trial and post trial process and the rights of the inmates in correctional institutions (prisons) tell us the principles of rule of law are limited only to the statute books. It may not be the case with Sri Lanka and this is the common phenomenon of many criminal justice systems in the world.

\section{Acknowledgments}

None.

\section{Conflicts of interest}

None.

\footnotetext{
${ }^{50}$ Article 27 (1) of the Constitution.

${ }^{51}$ Superintendant vs. Amarasinghe 2003 1SLR 270;Amal Suddath Silva vs. Kodithuwakku 1987 2SLR 119; Saman vs. Leeladasa 1989 1SLR 1; Lama Hewage Laal, Rani Fernando and others vs. Police O.I.C of Seeduwa 2005 1SLR 40; Anthony Michael Emmanuel Fernando vs. Sri Lanka (CCPR/ C83/D/1189/2003); Case No.4705/2001 and 4706/2001- The case of the two Tamil prisoners assassinated in Kalchura prison on 6th January 2000.
} 